\title{
CHANGES OVER FOURTEEN YEARS IN ADULT OBESITY IN ESTONIA: SOCIOECONOMIC STATUS AND USE OF OUTPATIENT HEALTH SERVICES
}

\author{
Mare Tekkel ${ }^{1,2}$, Tatjana Veideman ${ }^{1,2}$, Mati Rahu $^{1,2}$ \\ ${ }^{1}$ Department of Epidemiology and Biostatistics, National Institute for Health Development, Tallinn, Estonia \\ ${ }^{2}$ Estonian Centre of Behavioral and Health Sciences, Tartu-Tallinn, Estonia.
}

\begin{abstract}
SUMMARY
It has been noted that great socioeconomic and lifestyle changes have triggered an epidemic of obesity among Eastern Europeans. The objective of this study was to assess the change of adult obesity in Estonia by socioeconomic status and the use of outpatient healthcare services among obese individuals over time. It can be maintained that obesity distribution in Estonia in 1990-2004 developed similarly to an average Western country and, regardless of an increasing level of male obesity, obesity prevalence for 16-64 year-olds was on the average level in Europe in 2004 $-14.0 \%$ for men and $14.9 \%$ for women. Change in obesity prevalence correlates quite well with changes in the economy in Estonia. From studied socioeconomic variables only age and education (among women) strongly affect the change in obesity level. Obese individuals used outpatient medical care slightly differently compared to individuals with a normal BMI.
\end{abstract}

Key words: obesity trends, socioeconomic status, use of healthcare services, Estonia

Address for correspondence: M. Tekkel, National Institute for Health Development, Hiiu 42, 11619 Tallinn, Estonia. E-mail: mare.tekkel@tai.ee

\section{INTRODUCTION}

Obesity is increasing worldwide, more rapidly in developing countries, and is about to overtake smoking as the main preventable cause of death in Western countries $(1,2)$. Increasing obesity is becoming an economic issue to be reckoned with. Obesity generally goes hand in hand with a more pronounced utilization of out- and inpatient health services which raises health care costs (3-6). It has been noted that great socioeconomic and lifestyle changes have triggered an epidemic of obesity among Eastern Europeans (7), yet more detailed information, especially concerning the developments that lead to the current situation, has not drawn much interest so far.

Estonia underwent a number of political, economic and social changes after 1991. These processes affected Estonians and Russians (who make up the majority of non-Estonians) differently (8). Estonia currently belongs to the group of high Human Development Index (HDI) countries and is relatively urbanized, yet the majority of health behavior variables act differently in Tallinn (the capital of Estonia), other smaller towns and the countryside (9). Since 1991, the population of Estonia has been declining, mainly due to negative natural growth and emigration. The size of the population was 1,569,174 in January 1990 and 1,349,290 in 2004; the percentage of Estonians in the population was 61.5 and 68.6, respectively; the percentage of Russians has remained at approximately 26 since 2000 (earlier data are not available) (10). Estonian health insurance relies on the principle of solidarity (11).

The objective of this study was to assess the change of adult obesity in Estonia by socioeconomic status and the use of outpatient healthcare services among obese individuals over time.

\section{MATERIAL AND METHODS}

Data for this analysis were drawn from a series of Health Behavior Surveys among Estonian Adult Population which form a part of the Finbalt Health Monitor co-operative survey (12) and were performed among the adult population in Estonia each even year since 1990. The Tallinn Medical Research Ethics Committee approved the study. All studies were conducted as postal questionnaire surveys on the basis of a common methodology and employed a questionnaire (in Estonian or Russian) that largely contains identical questions. A simple random sampling (aged 16-64 years, 18-64 in 1990) from the National Population Register was used. The studies were carried out during four periods each reflecting specificity of the local economic development (13): I- 1990, 1992, 1994 (great political changes, deep economic depression), II - 1996, 1998 (beginning of economic growth), III -2000, 2002 and IV - 2004 (most economically successful years). The sample size per study was 1,500 in study period I, 2,000 in II and III, and 5,000 in IV. Body mass index (BMI) - body weight $(\mathrm{kg})$ divided by height $(\mathrm{m})$ squared - was calculated based on self-reported weight and height. Normal weight was defined as $\mathrm{BMI}=18.5-24.9$ and obesity as $\mathrm{BMI} \geq 30.0$.

Education, residence, ethnicity and income were used as socioeconomic variables. The highest educational level was designated as follows: basic education corresponds to up to nine school years/years of school, secondary education to $10-12$ and university education to $\geq 13$ study years. Only data specifying respondents' educational level in this manner were available for all studies. Some changes in the education system throughout the timespan of the study did not have a great impact 
on assessing educational level. To compare obesity risk in real rural and real urban residents, place of residence (based on data from the population register) was divided into three groups: Tallinn ("real urban"), other towns and rural. Pursuant to the corresponding law, the National Population Register registers ethnicity according to self-assessment; this is not related to citizenship. Ethnicity was analysed in two groups - Estonian and non-Estonian. Starting from 1996, respondents were asked about their average monthly net income from all sources for the past 12 months per member of the household. In the situation where distribution of salaries and income from other sources in Estonia was extremely skewed towards the lower direction (10), income quantiles could not be used, thus a relative scale was utilized. In the first group ("very low"), the relevant income was below the national minimum salary, in the "low" group, below the average, in the "middle" group, more or less on the level of the average level, and in the "high" group, exceeded the average salary in the year of the study.

The majority of family and special medical care users in Estonia utilize the relevant outpatient health care services once or twice per year (9). As healthy individuals can also require family physician or medical specialist services (preemptive health check, new glasses, routine visits for contraceptive pills etc.), yet for reasons primarily unrelated to their BMI, the group of individuals who had more than two primary or special care visits in the past 12 months was selected for analysis.

\section{Statistical analysis}

Obesity prevalence was calculated by age, gender, socioeconomic variables and study period. The strength of associations between obesity and some variables (ethnicity, residence, income, use of health care service) was estimated by odds ratios (OR) and $95 \%$ confidence intervals $(\mathrm{CI})$ using logistic regression. The crude and adjusted ORs for obesity were calculated, adjustment was done for age, and age and education. The Cuzick's test for trend was used within each subgroup of variables by study period. Statistical analysis was performed with the STATA 6.0 and Visual FoxPro 6.0 software.

\section{RESULTS}

In the postal surveys, a response proportion decreased from $70.3 \%$ in 1990 to $61.6 \%$ in 2004 , yet was quite high for the youngest individuals. For example, in the most recent study, response proportion for women in the youngest age group was higher than that in the next age group, for men than that in the next two age groups. Non-respondents can be described on the basis of only a few characteristics - they included more men; the percentage share of rural residents, age groups and different ethnicity groups differed per study. All of the studies together included 11,774 respondents in total, 1,614 of whom fell into the obese category. In each of the four study periods, there were generally more

Table 1. Prevalence of obesity by age, socioeconomic variables, gender and study period; Estonia, 1990-2004

\begin{tabular}{|c|c|c|c|c|c|c|c|c|c|}
\hline \multirow{3}{*}{\multicolumn{2}{|c|}{ Characteristic }} & \multicolumn{8}{|c|}{ Prevalence $\%$ by study period } \\
\hline & & \multicolumn{4}{|c|}{ Men } & \multicolumn{4}{|c|}{ Women } \\
\hline & & $\begin{array}{c}\mathrm{I} \\
(\mathrm{n}=1445)^{\mathrm{a}}\end{array}$ & $\begin{array}{c}\text { II } \\
(n=1248)\end{array}$ & $\begin{array}{c}\text { III } \\
(n=1079)\end{array}$ & $\underset{(n=1319)}{\text { IV }}$ & $\begin{array}{c}I \\
(n=1793)\end{array}$ & $\begin{array}{c}\text { II } \\
(n=1580)\end{array}$ & $\begin{array}{c}\text { III } \\
(n=1555)\end{array}$ & $\underset{\substack{\text { IV } \\
(n=1755)}}{ }$ \\
\hline \multirow{6}{*}{$\begin{array}{l}\text { Age } \\
\text { (years) }\end{array}$} & $16-24$ & 1.1 & 2.4 & 0.9 & 2.5 & 2.5 & 0.8 & 2.7 & 0.9 \\
\hline & $25-34$ & 5.4 & 6.5 & 10.1 & $11.1^{\mathrm{p}}$ & 7.1 & 6.4 & 5.8 & 5.7 \\
\hline & $35-44$ & 11.1 & 13.0 & 12.3 & $18.7^{p}$ & 16.2 & 12.9 & 12.2 & 14.2 \\
\hline & $45-54$ & 16.9 & 15.7 & 19.1 & 16.5 & 24.9 & 22.3 & 19.1 & 21.0 \\
\hline & $55-64$ & 19.5 & 14.4 & 20.1 & 24.4 & 28.7 & 27.4 & 31.7 & 29.1 \\
\hline & $16-64$ & 11.1 & 10.3 & 12.4 & $14.0^{p}$ & 17.1 & 14.5 & 15.0 & 14.9 \\
\hline \multirow{3}{*}{ Education } & basic & 17.7 & 11.3 & 13.4 & 13.8 & 28.9 & 22.1 & 23.8 & 24.6 \\
\hline & secondary & 9.3 & 7.1 & 12.3 & $14.3^{p}$ & 13.5 & 14.6 & 12.5 & 13.0 \\
\hline & university & 8.3 & 10.8 & 16.6 & $13.6^{p}$ & 11.4 & 8.9 & 12.5 & 8.5 \\
\hline \multirow{3}{*}{ Residence } & Tallinn & 8.9 & 10.2 & 13.6 & $14.0^{P}$ & 13.7 & 13.0 & 12.3 & 14.4 \\
\hline & other town & 10.9 & 8.8 & 11.3 & 12.8 & 18.6 & 14.4 & 15.2 & $13.6^{p}$ \\
\hline & countryside & 14.1 & 12.9 & 12.8 & 15.3 & 19.0 & 16.2 & 17.8 & 16.7 \\
\hline \multirow{2}{*}{ Ethnicity } & Estonian & 10.3 & 11.2 & 12.5 & $14.7^{p}$ & 18.0 & 14.3 & 13.5 & $12.2^{p}$ \\
\hline & other & 11.9 & 8.7 & 13.1 & 12.4 & 16.2 & 14.9 & 18.3 & $20.4^{p}$ \\
\hline \multirow{4}{*}{ Income } & very low & - & 9.0 & 11.8 & 11.1 & - & 15.8 & 17.5 & 15.0 \\
\hline & low & - & 12.3 & 13.8 & 16.9 & - & 13.9 & 16.3 & 18.2 \\
\hline & middle & - & 9.3 & 14.4 & 12.0 & - & 7.9 & 10.3 & 10.8 \\
\hline & high & - & 21.4 & 9.8 & 19.6 & - & 3.0 & 10.6 & 8.9 \\
\hline
\end{tabular}

a number of persons studied, ${ }^{\mathrm{p} p}$ for trend $<0.05$ 
Table 2. Odds ratio (OR) with $95 \%$ confidence interval (Cl) for obesity by age and socioeconomic variables, gender groups and study period; Estonia, 1990-2004

\begin{tabular}{|c|c|c|c|c|c|c|c|c|c|c|}
\hline \multirow{3}{*}{\multicolumn{2}{|c|}{ Characteristic }} & \multirow{4}{*}{$\begin{array}{l}\text { Model } \\
-\end{array}$} & \multicolumn{8}{|c|}{ OR $(95 \% \mathrm{Cl})$ by study period } \\
\hline & & & \multicolumn{4}{|c|}{ Men } & \multicolumn{4}{|c|}{ Women } \\
\hline & & & I & ॥ & III & IV & I & ॥ & III & IV \\
\hline \multirow{5}{*}{$\begin{array}{l}\text { Age } \\
\text { (years) }\end{array}$} & $16-24^{b}$ & & - & - & - & - & - & - & - & - \\
\hline & $25-34$ & & 1.00 & 1.00 & 1.00 & 1.00 & 1.00 & 1.00 & 1.00 & 1.00 \\
\hline & $35-44$ & $\mathrm{u}$ & $\begin{array}{c}2.19 \\
(1.24-3.88)\end{array}$ & $\begin{array}{c}2.14 \\
(1.16-3.94)\end{array}$ & $\begin{array}{c}1.26 \\
(0.69-2.31)\end{array}$ & $\begin{array}{c}1.84 \\
(1.14-2.98)\end{array}$ & $\begin{array}{c}2.55 \\
(1.61-4.04)\end{array}$ & $\begin{array}{c}2.17 \\
(1.26-3.75)\end{array}$ & $\begin{array}{c}2.27 \\
(1.24-4.14)\end{array}$ & $\begin{array}{c}2.73 \\
(1.56-4.78)\end{array}$ \\
\hline & $45-54$ & $\mathrm{u}$ & $\begin{array}{c}3.57 \\
(2.07-6.14)\end{array}$ & $\begin{array}{c}2.67 \\
(1.43-5.00)\end{array}$ & $\begin{array}{c}2.12 \\
(1.19-3.77)\end{array}$ & $\begin{array}{c}1.59 \\
(0.97-2.59)\end{array}$ & $\begin{array}{c}4.37 \\
(2.78-6.84)\end{array}$ & $\begin{array}{c}4.23 \\
(2.53-7.06)\end{array}$ & $\begin{array}{c}3.87 \\
(2.18-6.86)\end{array}$ & $\begin{array}{c}4.40 \\
(2.61-7.44)\end{array}$ \\
\hline & $55-64$ & u & $\begin{array}{c}4.25 \\
(2.40-7.51)\end{array}$ & $\begin{array}{c}2.41 \\
(1.28-4.53)\end{array}$ & $\begin{array}{c}2.25 \\
(1.27-3.99)\end{array}$ & $\begin{array}{c}2.58 \\
(1.59-4.19)\end{array}$ & $\begin{array}{c}5.30 \\
(3.39-8.28)\end{array}$ & $\begin{array}{c}5.54 \\
(3.34-9.19)\end{array}$ & $\begin{array}{c}7.59 \\
(4.35-13.24)\end{array}$ & $\begin{array}{c}6.77 \\
(4.05-11.32)\end{array}$ \\
\hline \multirow{3}{*}{ Education } & basic & & 1.00 & 1.00 & 1.00 & 1.00 & 1.00 & 1.00 & 1.00 & 1.00 \\
\hline & secondary & a & $\begin{array}{c}0.71 \\
(0.44-1.15)\end{array}$ & $\begin{array}{c}0.66 \\
(0.37-1.20)\end{array}$ & $\begin{array}{c}0.85 \\
(0.50-1.45)\end{array}$ & $\begin{array}{c}0.85 \\
(0.53-1.36)\end{array}$ & $\begin{array}{c}0.64 \\
(0.43-0.94)\end{array}$ & $\begin{array}{c}0.92 \\
(0.59-1.42)\end{array}$ & $\begin{array}{c}0.57 \\
(0.36-0.91)\end{array}$ & $\begin{array}{c}0.45 \\
(0.29-0.68)\end{array}$ \\
\hline & university & a & $\begin{array}{c}0.49 \\
(0.28-0.86)\end{array}$ & $\begin{array}{c}0.88 \\
(0.47-1.66)\end{array}$ & $\begin{array}{c}0.93 \\
(0.52-1.66)\end{array}$ & $\begin{array}{c}0.65 \\
(0.37-1.15)\end{array}$ & $\begin{array}{c}0.40 \\
(0.26-0.61)\end{array}$ & $\begin{array}{c}0.37 \\
(0.22-0.63)\end{array}$ & $\begin{array}{c}0.47 \\
(0.29-0.78)\end{array}$ & $\begin{array}{c}0.22 \\
(0.13-0.36)\end{array}$ \\
\hline \multirow{3}{*}{ Residence } & Tallinn & & 1.00 & 1.00 & 1.00 & 1.00 & 1.00 & 1.00 & 1.00 & 1.00 \\
\hline & other town & $a+e$ & $\begin{array}{c}1.21 \\
(0.79-1.87)\end{array}$ & $\begin{array}{c}0.87 \\
(0.54-1.41)\end{array}$ & $\begin{array}{c}0.85 \\
(0.53-1.37)\end{array}$ & $\begin{array}{c}0.82 \\
(0.53-1.26)\end{array}$ & $\begin{array}{c}1.45 \\
(1.06-1.98)\end{array}$ & $\begin{array}{c}1.11 \\
(0.77-1.61)\end{array}$ & $\begin{array}{c}1.28 \\
(0.88-1.87)\end{array}$ & $\begin{array}{c}0.79 \\
(0.55-1.14)\end{array}$ \\
\hline & countryside & $a+e$ & $\begin{array}{c}1.65 \\
(1.03-2.63)\end{array}$ & $\begin{array}{c}1.26 \\
(0.77-2.06)\end{array}$ & $\begin{array}{c}0.87 \\
(0.53-1.42)\end{array}$ & $\begin{array}{c}1.01 \\
(0.66-1.55)\end{array}$ & $\begin{array}{c}1.43 \\
(1.00-2.05)\end{array}$ & $\begin{array}{c}1.09 \\
(0.73-1.63)\end{array}$ & $\begin{array}{c}1.27 \\
(0.84-1.91)\end{array}$ & $\begin{array}{c}0.92 \\
(0.64-1.34)\end{array}$ \\
\hline \multirow[b]{2}{*}{ Ethnicity } & Estonian & & 1.00 & 1.00 & 1.00 & 1.00 & 1.00 & 1.00 & 1.00 & 1.00 \\
\hline & other & $a+e$ & $\begin{array}{c}1.26 \\
(0.90-1.78)\end{array}$ & $\begin{array}{c}0.74 \\
(0.50-1.11)\end{array}$ & $\begin{array}{c}1.01 \\
(0.65-1.57)\end{array}$ & $\begin{array}{c}0.87 \\
(0.60-1.25)\end{array}$ & $\begin{array}{c}0.90 \\
(0.69-1.17)\end{array}$ & $\begin{array}{c}1.08 \\
(0.80-1.46)\end{array}$ & $\begin{array}{c}1.66 \\
(1.20-2.30)\end{array}$ & $\begin{array}{c}1.95 \\
(1.45-2.61)\end{array}$ \\
\hline \multirow{4}{*}{ Income } & very low & & - & 1.00 & 1.00 & 1.00 & - & 1.00 & 1.00 & 1.00 \\
\hline & low & $a+e$ & - & $\begin{array}{c}1.55 \\
(1.01-2.39)\end{array}$ & $\begin{array}{c}1.23 \\
(0.77-1.94)\end{array}$ & $\begin{array}{c}1.73 \\
(1.15-2.62)\end{array}$ & - & $\begin{array}{c}0.95 \\
(0.66-1.36)\end{array}$ & $\begin{array}{c}0.86 \\
(0.61-1.22)\end{array}$ & $\begin{array}{c}1.24 \\
(0.90-1.72)\end{array}$ \\
\hline & middle & $a+e$ & - & $\begin{array}{c}1.36 \\
(0.63-2.93)\end{array}$ & $\begin{array}{c}1.39 \\
(0.81-2.38)\end{array}$ & $\begin{array}{c}1.47 \\
(0.88-2.44)\end{array}$ & - & $\begin{array}{c}0.56 \\
(0.25-1.21)\end{array}$ & $\begin{array}{c}0.52 \\
(0.32-0.83)\end{array}$ & $\begin{array}{c}0.90 \\
(0.57-1.42)\end{array}$ \\
\hline & high & $a+e$ & - & $-b$ & $\begin{array}{c}0.90 \\
(0.43-1.87)\end{array}$ & $\begin{array}{c}3.04 \\
(1.69-5.47)\end{array}$ & - & $-b$ & $\begin{array}{c}0.72 \\
(0.38-1.38)\end{array}$ & $\begin{array}{c}0.89 \\
(0.44-1.80)\end{array}$ \\
\hline
\end{tabular}

${ }^{\mathrm{b}}$ not enough obese individuals in group, $\mathrm{u}$ - unadjusted, a - adjusted for age, a+e - adjusted for age and education

women among respondents as opposed to men (Table 1) as well as among obese respondents - 301, 226, 230 and 258 women, and $159,126,132$ and 182 men, respectively.

Table 1 presents prevalence of obesity by age, socioeconomic variables and study period. An increasing trend in obesity prevalence was confirmed ( $\mathrm{p}$ for trend $<0.05$ ) in the whole sample as well as in certain socioeconomic variable groups of men and in non-Estonian women. A consistent decreasing trend in obesity prevalence was revealed for ethnical Estonian women and women living in other towns than the capital.

Table 2 presents obesity OR within age and socioeconomic variable groups by study period. In all periods, obesity risk significantly increased with age (as compared to 25-34 year-olds) for both genders, particularly in women. There were only a few obese individuals among the youngest respondents in all periods as well as in the higher income group in period II. Consistent decrease of obesity OR was present for women with secondary and university education (as compared to the basic education group) in nearly all periods. Only period I showed a relation between the risk of being obese and residence in the countryside. Starting from period III, obesity OR for non-Estonian women was higher than that for ethnic Estonian women. Only in the last period, the risk of being obese increased with income for men; for women this correlation tended to be inverse in all periods.

Data presented in Table 3 characterize the use of certain outpatient health services by normal weight and obese individuals by study period. In both groups, the percentage of individuals who used dental care services decreased, and the percentage of family physician and specialized medical care users increased among men and women. The likelihood of visiting the dentist for obese men was somewhat higher for the last two study periods, and somewhat lower in all periods for obese women; the likelihood of other outpatient visits was significantly higher among all obese individuals in the last period as compared to individuals with normal weight. Data concerning hospitalization exist only for the last two periods. The likelihood of being hospitalized was the same for all men and somewhat higher for obese women as compared to women with normal weight (data not shown). 
Table 3. Prevalence and age+education adjusted odds ratio (OR) with $95 \%$ confidence interval (Cl) for some outpatient health care services use in the past 12 months by BMI, study period and gender; Estonia, 1990-2004

\begin{tabular}{|c|c|c|c|c|c|c|c|}
\hline \multirow{2}{*}{ Characteristic } & \multirow{2}{*}{ Gender } & \multirow{2}{*}{ BMI } & \multirow{2}{*}{ Measure } & \multicolumn{4}{|c|}{ Prevalence $(\%)$ and $\mathrm{OR}(95 \% \mathrm{Cl})$ by study period } \\
\hline & & & & I & $\|$ & III & IV \\
\hline \multirow{8}{*}{$\begin{array}{l}\text { Dentist } \\
\text { visits }\end{array}$} & \multirow{4}{*}{ men } & normal & \multirow{2}{*}{ prevalence } & 52.3 & 47.4 & 46.4 & 37.9 \\
\hline & & obese & & 47.8 & 42.9 & 48.5 & 38.8 \\
\hline & & normal & \multirow{2}{*}{$\begin{array}{c}\text { OR } \\
(95 \% \mathrm{Cl})\end{array}$} & 1.00 & 1.00 & 1.00 & 1.00 \\
\hline & & obese & & $\begin{array}{c}0.96 \\
(0.67-1.39)\end{array}$ & $\begin{array}{c}0.96 \\
(0.64-1.44)\end{array}$ & $\begin{array}{c}1.32 \\
(0.88-1.99)\end{array}$ & $\begin{array}{c}1.28 \\
(0.90-1.84)\end{array}$ \\
\hline & \multirow{4}{*}{ women } & normal & \multirow{2}{*}{ prevalence } & 74.8 & 70.5 & 68.6 & 56.0 \\
\hline & & obese & & 63.5 & 60.6 & 55.2 & 45.1 \\
\hline & & normal & \multirow{2}{*}{$\begin{array}{c}\text { OR } \\
(95 \% \mathrm{Cl})\end{array}$} & 1.00 & 1.00 & 1.00 & 1.00 \\
\hline & & obese & & $\begin{array}{c}0.75 \\
(0.55-1.02)\end{array}$ & $\begin{array}{c}0.86 \\
(0.61-1.21)\end{array}$ & $\begin{array}{c}0.70 \\
(0.50-0.97)\end{array}$ & $\begin{array}{c}0.87 \\
(0.64-1.19)\end{array}$ \\
\hline \multirow{8}{*}{$\begin{array}{l}\text { Other } \\
\text { outpatient } \\
\text { visits }^{\mathrm{a}} \\
>2 \text { times }\end{array}$} & \multirow{4}{*}{ men } & normal & \multirow{2}{*}{ prevalence } & 17.9 & 20.4 & 28.9 & 30.6 \\
\hline & & obese & & 27.0 & 26.2 & 31.8 & 41.6 \\
\hline & & normal & \multirow{2}{*}{$\begin{array}{c}\text { OR } \\
(95 \% \mathrm{Cl})\end{array}$} & 1.00 & 1.00 & 1.00 & 1.00 \\
\hline & & obese & & $\begin{array}{c}1.60 \\
(1.05-2.43)\end{array}$ & $\begin{array}{c}1.39 \\
(0.88-2.20)\end{array}$ & $\begin{array}{c}1.46 \\
(0.94-2.28)\end{array}$ & $\begin{array}{c}1.63 \\
(1.13-2.34)\end{array}$ \\
\hline & \multirow{4}{*}{ women } & normal & \multirow{2}{*}{ prevalence } & 34.3 & 35.4 & 40.5 & 49.9 \\
\hline & & obese & & 33.6 & 38.9 & 45.2 & 66.4 \\
\hline & & normal & \multirow{2}{*}{$\begin{array}{c}\text { OR } \\
(95 \% \mathrm{Cl})\end{array}$} & 1.00 & 1.00 & 1.00 & 1.00 \\
\hline & & obese & & $\begin{array}{c}0.93 \\
(0.69-1.26)\end{array}$ & $\begin{array}{c}1.36 \\
(0.98-1.90)\end{array}$ & $\begin{array}{c}1.26 \\
(0.91-1.73)\end{array}$ & $\begin{array}{c}2.09 \\
(1.52-2.86)\end{array}$ \\
\hline
\end{tabular}

a family physician and specialty care

\section{DISCUSSION AND CONCLUSIONS}

To the little that is known about Eastern Europe, this study adds new information on the current obesity level and on its change in 1990-2004 in Estonia. The strength of the study lies in the data presented having been drawn from eight surveys with quite a high response proportion, utilizing the same methodology and a random sampling from the population. It was found that although obesity prevalence in Estonia has increased for men since 1996/1998, it has remained more or less stable for women, and was on an average European level for both genders in 2004 (14.0\% for men and $14.9 \%$ for women). In all study periods obesity prevalence was somewhat higher for women than for men; the difference, however, decreased from $6.0 \%$ to $0.9 \%$. For the first time, the indicator was higher for men than for women among 25-34 yearolds in 2000/2002. The risk of being obese significantly increased with age in all study periods for both genders.

Obesity prevalence has continuously increased for adults throughout Europe and is generally higher for women - 10-25\%, compared to $10-20 \%$ in men (6); in Russia, it reached $10.3 \%$ in men and $21.6 \%$ in women by the year $2000(1,14)$. The relevant general indicator in the United States reached $30 \%$ during the past decade (15). In countries that have chosen a more Western development route, obesity level for men in certain age groups overtakes that of women $(16,17)$. This is particularly clearly evident in the difference of male/female obesity distribution in former West and East Germany (18). It seems that in developed societies, women have a more negative attitude towards obesity as compared to men; they are more influenced by public negative attitudes towards obesity and by certain social-environmental factors $(19,20)$. It is characteristic of all developed countries for the obesity level to increase significantly with age (21).

Next to age, education had the most pronounced effect on change in obesity level in Estonia. For men, a decreasing tendency in obesity prevalence was noted only in individuals with basic education and, as there was an increase for others, their obesity levels in 2004 were rather similar irrespective of educational level. At the same time a decreasing tendency in obesity prevalence was seen in women irrespective of their education level. However, the risk of being obese was lower for women with higher education than those with basic education in nearly all study periods.

In westernized countries, obesity is more common among individuals with a lower educational level, especially in the case of women $(14,20-24)$ and urban residents (25). Among men, the studies conducted in 14 developing countries found either a positive relation or the absence of a relation and, among women, a mostly negative association between educational level and obesity (1).

Besides age and education, the effect of other socioeconomic factors on obesity was, in a large part, non-significant. This has also been noted in Estonia before, and it has been suggested that the problem is more generalized than expected (26). After 
overcoming the political changes and economic difficulties, obesity OR was not related to the place of residence. The study results highlight the fact that registered residence today might not reflect an individual's lifestyle. For example, new residential areas in Estonia, established in the immediate proximity of cities, are located on rural territory, yet the lifestyle of residents there is predominantly urban. An interesting result was the change in obesity prevalence for women depending on ethnicity, declining for Estonian women, yet notably increasing for others. Thus obesity change for non-Estonians, the majority of whom are Russians, was similar to that in Russia $(1,14)$. Obesity OR for non-Estonian women exceeded the relevant indicator for Estonian women in 2000/2002 when the economic situation was consistently improving. The effect of income was different for men and women - for men with higher income there was a positive correlation with obesity; the corresponding correlation for women was inverse. It is noticeable that for some groups with an increased poverty risk (non-Estonians, individuals with basic education, men who have secondary education or live in smaller towns), obesity prevalence that had declined in 1996/1998, started to increase in accord with economic success. For rural men, an increase in obesity appeared only in 2004.

In an extensive meta-analysis, it was discovered that, for men in high- and medium-HDI countries, findings between obesity and socioeconomic status were predominantly non-significant or curvilinear; for women in high-HDI countries the majority of associations were negative (27). Most studies have found a negative correlation between salary and body weight among women, yet have been unable to prove which is cause and which is effect (3). A reason behind the much weaker link between income and body weight among men could be that low-income men engage in more manual occupational labor and experience higher levels of physical activity (15). Obesity and socioeconomic status (expressed through income, education, etc.) are certainly interconnected $(3,15,28)$.

The prevalence of outpatient visits to a family physician or medical specialist in the past 12 months increased for everyone during the period studied in Estonia, yet especially - by 32.8\% for obese women. In addition to accumulating health problems, women's greater desire to get weight-loss related counseling from a physician can be one of the factors for the significant increase of OR for those visits among obese individuals (as compared to persons with normal BMI) in the last study period. The reason behind the continuous decline in dental visits is certainly the relevant increase in the cost of the service as adults (19 and older) in Estonia have to cover the full cost of dental treatment themselves (11). Obese women visited the dentist somewhat less frequently than women with normal weight. This is consistent with one other study (29).

A limitation of the study is the use of self reported weight and height for respondents. Normally, such data result in underestimated BMI (30). It is revealed that this is more common among overweight/obese men than women and is more frequently found among older individuals, individuals with relatively low education or lower income levels (31); and reversely, is more noteworthy in women and varies significantly among ethnic groups (32). It is interesting to note that obesity prevalence for women, calculated on the basis of explicit measurement results in Estonia in 1997 (26) was lower than that calculated in the same age group on the basis of the results of the postal survey in 1994/1996/1998 (33). It has been found that among women from high-HDI countries, the proportion of negative associations was lower in the measured data subset than in the self-reported data subset (27). Limited information on the distribution of socioeconomic factors within the sample frame and among non-respondents does not allow for speculations on the effect of non-response on prevalence estimates and associations over time. Although there were smaller response proportions in recent surveys, it does not inevitably mean that selection bias is growing and generalizability to the target population is decreasing over time (34). Earlier Finbalt data analysis did not determine a straightforward direction of non-response in estimating health behavior prevalence (35).

In conclusion, obesity is a public health problem in Estonia, but the dimensions of obesity are similar to those observed in an average Western country. From studied socioeconomic variables only age and education (among women) strongly affect the change in obesity level over time. Obese individuals used outpatient medical care slightly differently than individuals with a normal BMI. National obesity prevention programs should be developed based on epidemiologic studies and monitoring of population health and health determinants.

\section{Acknowledgements}

The research was supported by the Estonian Ministry of Social Affairs, and the Estonian Ministry of Education and Research (target funding 01921112s02 and SF0940026s07). The authors thank Tiiu Vahtramäe for technical assistance,

\section{REFERENCES}

1. Monteiro CA, Moura EC, Conde WL, Popkin BM. Socioeconomic status and obesity in adult populations of developing countries: a review. Bull World Health Organ. 2004 Dec;82(12):940-6.

2. Skidmore PM, Yarnell JW. The obesity epidemic: prospects for prevention. QJM. 2004 Dec;97(12):817-25.

3. Finkelstein EA, Ruhm CJ, Kosa KM. Economic causes and consequences of obesity. Annu Rev Public Health. 2005;26:239-57.

4. Raebel MA, Malone DC, Conner DA, Xu S, Porter JA, Lanty FA. Health services use and health care costs of obese and nonobese individuals. Arch Intern Med. 2004 Oct 25;164(19):2135-40.

5. Von Lengerke T, Happich M, Reitmeir P, John J; Kora Study Group. Utilization of out- and inpatient health services by obese adults: a population-based study in the Augsburg region, Germany. Gesundheitswesen. 2005 Aug;67 Suppl 1:S150-7.

6. Sturm R. The effects of obesity, smoking, and drinking on medical problems and costs. Health Aff (Millwood). 2002 Mar-Apr;21(2):245-53.

7. Spritzer DA. Obesity epidemic migrates east. CMAJ. 2004 Nov 9;171(10):1159.

8. Leinsalu $\mathrm{M}$, Vågerö $\mathrm{D}$, Kunst $\mathrm{AE}$. Increasing ethnic differences in mortality in Estonia after the collapse of the Soviet Union. J Epidemiol Community Health. 2004 Jul;58(7):583-9.

9. National Institute for Health Development. Health behavior among Estonian adult population, 2004. Tallinn: Tervise Arengu Instituut; 2005. (In Estonian.)

10. Statistics Estonia. Statistical database [Internet]. Tallinn: Statistics Estonia; 2010 [cited 2010 Aug 10]. Available from: http://pub.stat.ee/ px-web.2001/dialog/statfile1.asp.

11. Habicht T, Habicht J. Estonia: "good practice" in expanding health care coverage. In: Gottret P, Schieber GJ, Waters HR, editors. Good practices in health financing: lessons from reforms in low- and middle-income countries. Washington, DC: World Bank; 2008. p. 227-67.

12. Puska P, Helasoja V, Prättälä R, Kasmel A, Klumbiene J. Health behaviour in Estonia, Finland and Lithuania 1994-1998. Standardized comparison. Eur J Public Health. 2003 Mar;13(1):11-7. 
13. A short overview of Estonian economic development in 1993-2005 and prognosis for 2006. Eesti Majanduse Teataja. 2006;(176):10-1. (In Estonian.)

14. Jahns L, Baturin A, Popkin BM. Obesity, diet, and poverty: trends in the Russian transition to market economy. Eur J Clin Nutr. 2003 Oct;57(10):1295-302.

15. Chang VW, Lauderdale DS. Income disparities in body mass index and obesity in the United States, 1971-2002. Arch Intern Med. 2005 Oct $10 ; 165(18): 2122-8$

16. Wimmer K, Laubereau B, Wölke G, Döring A, Heinrich J. Weight gain in two adult cohorts in East and West Germany reunification. Cent Eur J Public Health. 2003 Dec;11(4):202-8.

17. Grabauskas V, Petkevičiene J, Klumbiene J, Vaisvalavičius V. The prevalence of overweight and obesity in relation to social and behavioral factors (Lithuanian health behavior monitoring). Medicina (Kaunas). 2003;39(12):1223-30.

18. Mensink GB, Lampert T, Bergmann E. Overweight and obesity in Germany 1984-2003. Bundesgesundheitsblatt Gesundheitsforschung Gesundheitsschutz. 2005 Dec;48(12):1348-56. (In German.)

19. Manios Y, Panagiotakos DB, Pitsavos C, Polychronopoulos E, Stefanadis C. Implication of socio-economic status on the prevalence of overweight and obesity in Greek adults: the ATTIKA study. Health Policy. 2005 Oct;74(2):224-32

20. Zhang Q, Wang Y. Trends in the association between obesity and socio-economic status in U.S. adults: 1971 to 2000. Obes Res. 2004 Oct;12(10):1622-32.

21. Rennie KL, Jebb SA. Prevalence of obesity in Great Britain. Obes Rev. 2005 Feb;6(1):11-2.

22. Cameron AJ, Welborn TA, Zimmet PZ, Dunstan DW, Owen N, Salmon J, et al. Overweight and obesity in Australia: the 1999-2000 Australian Diabetes, Obesity and Lifestyle Study (AusDiab). Med J Aust. 2003 May 5;178(9):427-32. Erratum in: Med J Aust. 2004 Apr 19;180(8):418.

23. Suadicani P, OleHein H, Gyntelberg F. Lifestyle, social class, and obesity - the Copenhagen Male Study. Eur J Cardiovasc Prev Rehabil. 2005 Jun;12(3):236-42.

24. Pikhart H, Bobak M, Malyutina S, Pajak A, Kubínová R, Marmot M. Obesity and education in three countries of the Central and Eastern Europe: the HAPIEE study. Cent Eur J Public Health. 2007 Dec;15(4):140-2.
25. Wilsgaard T, Jacobsen BK, Arnesen E. Determining lifestyle correlates of body mass index using multilevel analyses: the Tromsø Study, 1979-2001. Am J Epidemiol. 2005 Dec 15;162(12):1179-88.

26. Pomerleau J, Pudule I, Grinberga D, Kadziauskiene K, Abaravicius A, Bartkeviciute R, et al. Patterns of body weight in the Baltic Republics. Public Health Nutr. 2000 Mar;3(1):3-10.

27. McLaren L. Socioeconomic status and obesity. Epidemiol Rev. 2007;29:29-48.

28. Zagorsky JL. Is obesity as dangerous to your wealth as to your health? Res Aging. 2004 Jan;26(1):130-52.

29. Banerjea R, Findley PA, Sambamoorthi U. Disparities in preventive care by body mass index categories among women. Women Health. 2008;47(4):1-17.

30. Neovius M, Janson A, Rössner S. Prevalence of obesity in Sweden. Obes Rev. 2006 Feb;7(1):1-3.

31. Kuchler F, Variyam JN. Mistakes were made: misperception as a barrier to reducing overweight. Int J Obes Relat Metab Disord. 2003 Jul;27(7):85661.

32. Gillum RF, Sempos CT. Ethnic variation in validity of classification of overweight and obesity using self-reported weight and height in American women and men: the Third National Health and Nutrition Examination Survey. Nutr J. 2005 Oct 6;4:27.

33. Klumbiene J, Petkeviciene J, Helasoja V, Prättälä R, Kasmel A. Sociodemographic and health behaviour factors associated with obesity in adult populations in Estonia, Finland and Lithuania. Eur J Public Health. 2004 Dec;14(4):390-4.

34. Søgaard AJ, Selmer R, Bjertness E, Thelle D. The Oslo Health Study: The impact of self-selection in a large, population-based survey. Int $\mathrm{J}$ Equity Health. 2004 May 6;3(1):3.

35. Helasoja V, Prättälä R, Dregval L, Pudule I, Kasmel A. Late response and item nonresponse in the Finbalt Health Monitor survey. Eur J Public Health. 2002 Jun;12(2):117-23.

Received September 6, 2009 Accepted in revised form July 19, 2010 